\title{
Efektivitas Teknik Role Playing untuk Mengembangkan Perilaku Asertif Remaja
}

\author{
Herny Novianti \\ gusbrava_2111@yahoo.com
}

\begin{abstract}
Abstrak
This research aimed to produce effectiveness of role playing tehnicque for developing adolescence assertive behavior. The method of research used quasi-experimental research design with non-equivalent pretestposttest control group design. The sample in this study were adolescence of Child Social Welfare Institution (LKSA) Nugraha 2015, aged 15-17 years, totaling 28 adolescents. Data was collected by assertiveness instrument, arranged on the aspects of thought, feeling, and action. The results showed role playing tehnicque effective to develop adolescence assertive behavior, increased of ten indicator. of self respect and respect for others, positive thinking, responsible for the opinions expressed, open to change, confidence, self esteem, selfacceptance, listening to others, eye contact, give and receive feedback, indicators were not significant for empathy, open body posture, and participate in the association. Recommendations showed for guidance and counseling study program, child social welfare institution (LKSA) and further research.
\end{abstract}

Kata Kunci: Role Playing Tehnicque, Assertive Behavior

\section{PENDAHULUAN}

Remaja dalam melangsungkan kehidupannya, tidak terlepas dari permasalahan- permasalahan yang dihadapi, baik dari segi akademik maupun nonakademik. Hall memandang masa remaja sebagai masa "storm and stres", dimana remaja berupaya untuk menemukan jati diri dan aktualisasi diri. Dalam proses pencarian jati diri tersebut tidak selalu berjalan mulus, remaja juga dihadapkan kepada berbagai permasalahan termasuk dalam kesulitan mengungkapkan pikiran dan perasaan saat berinteraksi sosial.

Permasalahan tersebut terjadi juga kepada remaja yang tinggal di Lembaga Kesejahteraan Sosial Anak (LKSA). Bıçakçı (2011), yang menyatakan bahwa 63,2\% remaja yang tinggal di LKSA memiliki kepercayaan diri yang rendah. Sejalan dengan itu, Erim \& Cetin (Bıçakçı, 2011) menyatakan bahwa remaja di LKSA memiliki tingkat penghargaan diri yang lebih rendah, kecenderungan yang lebih tinggi untuk depresi dan dukungan sosial yang lebih rendah dibandingkan dengan remaja yang hidup bersama keluarga, serta cenderung berperilaku agresif. 
Hal tersebut dapat dipahami mengingat aspek kepribadian remaja yang menonjol dalam berinteraksi social adalah social cognition dan konformitas. Yusuf (2009, hlm. 13) menyatakan social cognition merupakan kemampuan memahami orang lain. Kemampun ini mendorong remaja untuk menjalin hubungan sosial dengan teman sebaya, sedangkan konformitas adalah kecenderungan untuk meniru, mengikuti opini, pendapat, nilai, kebiasaan, kegemaran atau keinginan orang lain. Perkembangan konformitas dapat memberikan dampak positif maupun negatif, tergantung kepada siapa atau kelompok mana remaja tersebut melakukan konformitasnya.

Remaja yang memiliki konformitas yang tinggi, ia akan mengikuti apa saja yang dikehendaki oleh kelompok teman sebayanya. Hal tersebut dapat dilihat ketika remaja dihadapkan pada stimulus yang ambigius dan tidak berstruktur ia jarang membangun sudut pandang sendiri yang stabil dalam menilai stimulus tersebut, dan pandangannya sering berubah ketika dihadapkan pada pandangan orang lain. Semakin rendah kepercayaan diri remaja terhadap penilaiannya sendiri, maka semakin tinggi konformitasnya (Effendi, 2013).

Sejalan dengan itu, Anindyajati dan Karima (2004) menyatakan remaja yang berperilaku asertif memiliki keyakinan serta keberanian untuk bertindak maupun berpendapat, walaupun tindakan dan pemikirannya berbeda dengan lingkungannya. Hal tersebut didukung oleh kepercayaan diri yang dimiliki oleh remaja, perasaan mampu, dan yakin akan dirinya sendiri. Beberapa ahli (Rees dan Graham, 1991; Bishop, 2007; Fajarwati, 2013) menyatakan kebebasan mengungkapkan pikiran dan pendapat merupakan bagian dari perilaku asertif, dimana individu mampu mengungkapkan pikiran dan pendapatnya dengan jelas, langsung dan tepat dengan tetap menghormati dirinya sendiri dan orang lain. Perilaku asertif tidak dilatar belakangi oleh maksud-maksud tertentu, seperti untuk memanipulasi, memanfaatkan, memperdaya ataupun mencari keuntungan dari pihak lain, seperti yang dinyatakan oleh Butler (Towned, 2007) bahwa perilaku asertif merupakan life postion yang sehat (I'm Ok You're Ok). ${ }^{3}$

Penelitian yang dilakukan oleh Ngindang (2002) terhadap 43 remaja yang tinggal di panti asuhan Sancta Maria Boro Kalibawang Yogyakarta, yang antara lain menunjukkan bahwa 16,28\% memiliki tingkat asertif tinggi; 72,09\% memiliki tingkat asertif sedang; dan 11,63\% memiliki tingkat asertif rendah. Survei perilaku asertif remaja juga dilakukan oleh peneliti dengan menggunakan instrumen perilaku asertif di lima LKSA Kota Bandung yang melibatkan 52 remaja berusia 15-17 tahun menunjukkan bahwa 50\% remaja LKSA berada pada kategori asertif, dan 50\% remaja LKSA berada pada kategori tidak asertif. Instrumen yang diberikan tersebut meliputi aspek pikiran, perasaan, dan tindakan.

Paparan fakta diatas menunjukkan bahwa perilaku asertif remaja LKSA perlu dikembangkan, seperti yang dinyatakan oleh Alberti dan Emmons (Peneva dan Mavrodiev, 2013) bahwa perilaku asertif perlu dikembangkan dalam diri setiap remaja agar ia memiliki kontrol diri dan mempunyai kemampuan untuk berkata "tidak" ketika menolak ajakan negatif teman. Berdasarkan hasil penelitian 
tersebut, diperoleh gambaran bahwa remaja yang LKSA memiliki permasalahanpermasalahan yang perlu diselesaikan dengan cara yang tepat. Hurlock menyatakan bahwa keberhasilan remaja dalam usaha untuk memperbaiki kepribadiannya bergantung pada banyak faktor, yaitu: (1) penentuan ideal- ideal yang realistik dan dapat mereka capai. Jika tidak, remaja akan mengalami kegagalan, perasaan tidak mampu, dan rendah diri; (2) penilaian yang realistik mengenai kekuatan dan kelemahannya. Perbedaan yang mencolok antara kepribadian yang sebenarnya dengan ego ideal akan menimbulkan kecemasan, perasaan tidak enak, tidak bahagia, dan kecenderungan menggunakan reaksireaksi bertahan; (3) pembentukan konsep diri yang positif.

Dalam menentukan ideal- ideal yang realistik diperlukan keberanian untuk menuangkan apa yang dipikirkan, dirasakan dengan jujur dan tanggung jawab. Hal tersebut merupakan bagian dari perilaku asertif yang perlu dikembangkan di LKSA, karena ketika menjalani aktivitas seharian tidak semua remaja dapat berperilaku asertif. Lazarus (Pipas \& Jaradat, 2010: 50) mendefinisikan perilaku asertif sebagai kemampuan untuk berkata tidak, kemampuan untuk meminta bantuan, kemampuan mengekspresikan perasaan positif dan negatif, kemampuan untuk melakukan inisiasi, kemampuan untuk melanjutkan dan mengakhiri percakapan.

Berperilaku asertif bukan merupakan hal yang mudah dilakukan oleh remaja, akan tetapi ini bukanlah hal yang tidak mungkin terjadi, seperti yang dinyatakan oleh Willis \& Daisley (Mariani \& Andriani, 2005) bahwa asertif merupakan suatu bentuk perilaku dan bukan merupakan sifat kepribadian seseorang yang dibawa sejak lahir, sehingga dapat dipelajari meskipun pola kebiasaan seseorang mempengaruhi proses pembelajaran tersebut. Ia menegaskan bahwa semua orang dapat berperilaku agresif, pasif, maupun asertif. Sedangkan Rakos (Mariani \& Andriani,2005) berpendapat bahwa untuk berperilaku asertif, perlu dipelajari dan dilatih dibandingkan perilaku agresif dan pasif.

Fensterheim \& Baer (1980: 82) menyatakan bahwa banyak orang mempunyai kesulitan dalam berperilaku asertif, tidak karena adanya trauma yang tersembunyi dan sudah lama dilupakan, tetapi karena: (1) mereka selalu menghindari situasi yang tegas, atau (2) mereka tidak pernah belajar menjadi tegas.

Shan Rees dan Roderick S. Graham (2006:1) mengemukakan bahwa:

Being assertive also means taking responsibility for your life and your choices. It means making your own decisions, rather than simply drifting or going along with other people's choices. It means not blaming other people or 'circumstances' for what happens to you. If you take responsibility for your own life, you can change the parts that are not as you want them. If you blame outside circumstances for your life, it means you are helpless to change it. It is both challenging and exciting to know that we are the creators of our livesby our own thoughts and actions, we are responsible for what happens to us. 
Pernyataan tersebut menggambarkan bahwa jika individu memiliki perilaku asertif, dia akan memiliki tanggung jawab dan konsekuen dalam melaksanakan keputusannya sendiri, memiliki kebebasan dalam berpendapat, mengungkapkan perasaannya secara jujur dan terbuka dengan tetap memperhatikan pendapat orang lain dan tidak menyakitinya. Alberti dan Emmons (Peneva \& Mavrodiev, 2013: 8) menganggap bahwa self worth dalam perilaku asertif tidak hanya diinginkan, tetapi juga perlu dikembangkan dalam diri setiap orang. Mereka sepakat bahwa perilaku asertif bukan satu- satunya cara dalam menyelesaikan permasalan, tetapi dengan berperilaku asertif, masalah dapat diselesaikan dengan baik dan memadai.

Upaya yang dilakukan untuk mengembangkan perilaku asertif remaja LKSA yaitu melalui teknik role playing. Winkel (1997:117) menyatakan role playing sangat bermanfaat karena melalui interaksinya dengan anggota-anggota kelompok mereka memenuhi beberapa kebutuhan psikologis seperti kebutuhan untuk menyesuaikan diri dengan teman sebaya dan diterima oleh mereka, kebutuhan untuk bertukar pikiran dan berbagi perasaan, kebutuhan untuk memenuhi nilainilai kehidupan sebagai pegangan dan kebutuhan untuk menjadi lebih independen serta mandiri.

Melalui teknik role playing, remaja dapat mengeksplorasi hubungan dengan cara memeragakan dan mendiskusikannya sehingga secara bersama-sama dapat mengeksplorasi perasaan, sikap, nilai, dan berbagai strategi pemecahan masalah, serperti yang diungkapkan oleh Fannie Shaffel bahwa manusia adalah makhluk sosial yang memiliki kemampuan untuk mementaskan konflik, belajar mengambil peran orang lain, dan meneliti perilaku sosial. Dengan demikian, teknik role playing merupakan hal yang tepat diberikan sebagai layanan untuk mengembangkan perilaku asertif remaja LKSA.

\section{METODE}

Tujuan penelitian untuk menguji keefektifan teknik role playing dalm mengembangkan perilaku asertif remaja, sehingga metode penelitian yang digunakan adalah penelitian eksperimen. Penelitian eksperimen yang digunakan adalah penelitian eksperimen kuasi, dimana penelitian tetap memiliki kelompok kontrol, namun tidak dapat berfungsi sepenuhnya untuk mengontrol variabelvariabel luar yang mempengaruhi pelaksanaan eksperimen (Sugiyono, 2010).

Selain itu, menurut Cresswell (2008) metode eksperimen kuasi (quasi experimental) digunakan dalam penelitian eksperimen apabila mempunyai dua kelompok yang tidak dipilih secara acak. Mengingat penelitian mengenai teknik role playing untuk mengembangkan perilaku asertif remaja dilakukan dalam pembelajaran sehari-hari bukan dalam kondisi laboratorium, sehingga tidak memungkinkan mengontrol variabel lain selain variabel teknik role playing dan variabel perilaku asertif secara ketat. $^{9}$

Dengan demikian, metode penelitian yang cocok dalam penelitian ini adalah metode penelitian eksperimen kuasi dengan desain nonequivalent (pretest dan 
posttest) control group design, serta kelompok eksperimen maupun kelompok kontrol tidak dipilih secara acak. Proses pelaksanaan eksperimen pada penelitian ini yaitu: (1) kelas eksperimen dan kelas kontrol diberikan pretest, (2) perlakuan berupa pelaksanaan role playing diberikan kepada kelas eksperimen, sedangkan kelas kontrol tidak diberikan perlakuan, (3) kelas eksperimen dan kelas kontrol diberikan posttest. Adapun desain penelitian (Heppner, Wampold, dan Kivlinghan) disajikan pada Tabel 1 berikut.

Tabel 1. Desain Penelitian

\begin{tabular}{|l|l|l|l|}
\hline \multicolumn{1}{|c|}{ Kelas } & \multicolumn{1}{c|}{ Pretest } & \multicolumn{1}{c|}{ Perlakuan } & \multicolumn{1}{c|}{ Posttest } \\
\hline Eksperimen & $\mathrm{O}_{1}$ & $\mathrm{X}$ & $\mathrm{O}_{2}$ \\
\hline Kontrol & $\mathrm{O}_{3}$ & - & $\mathrm{O}_{4}$ \\
\hline
\end{tabular}

Keterangan:

$\mathrm{O}_{1}$ : Pretest untuk mengungkap kondisi awal perilaku asertif remaja kelas eksperimen.

$\mathrm{O}_{2}$ : Posttest untuk mengungkap kondisi akhir perilaku asertif remaja kelas eksperimen.

$\mathrm{X}$ : Perlakuan berupa teknik role playing untuk mengembangkan perilaku asertif remaja pada kelas eksperimen.

$\mathrm{O}_{3}$ : $\quad$ Pretest untuk mengungkap kondisi akhir perilaku asertif remaja kelas kontrol.

$\mathrm{O}_{4}$ : $\quad$ Posttest untuk mengungkap kondisi akhir perilaku asertif remaja kelas kontrol.

\section{HASIL PENELITIAN}

Hasil penelitian meliputi: (1) profil perilaku asertif remaja; (2) rumusan hipotetik role playing untuk mengembangkan perilaku aserti remaja; (3) gambaran keefektifan role playing dalam mengembangkan perilaku asertif remaja.

\section{A. Profil Perilaku Asertif Remaja}

Berikut diuraikan profil remaja di lima LKSA Kota Bandung, baik secara umum maupun secara khusus berdasarkan indikator perilaku asertif.

\section{Profil Perilaku Asertif Remaja}

Untuk menjawab pertanyaan penelitian terkait profil perilaku asertif remaja, peneliti menggunakan teknik presentase atau analisis statistik data kuantitatif yang telah diperoleh. Hasil penelitian menunjukkan profil perilaku asertif remaja di lima LKSA Kota Bandung secara umum adalah $50 \%$ berada pada kategori asertif dan $50 \%$ berada pada kategori tidak asertif. Secara lebih rinci profil perilaku asertif remaja LKSA disajikan pada Tabel 2 berikut ini.

\section{Tabel 2. Profil Perilaku Asertif Remaja LKSA Kota Bandung}

\begin{tabular}{|l|l|l|l|}
\hline Kategori & Rentang Skor & Frekuensi & Persentase \\
\hline Asertif & $\mathrm{X} \geq 130$ & 26 & $50 \%$ \\
\hline
\end{tabular}




\begin{tabular}{|l|l|l|l|}
\hline Tidak asertif & $\mathrm{X}<130$ & 26 & $50 \%$ \\
\hline Jumlah & 52 & $100 \%$ \\
\hline
\end{tabular}

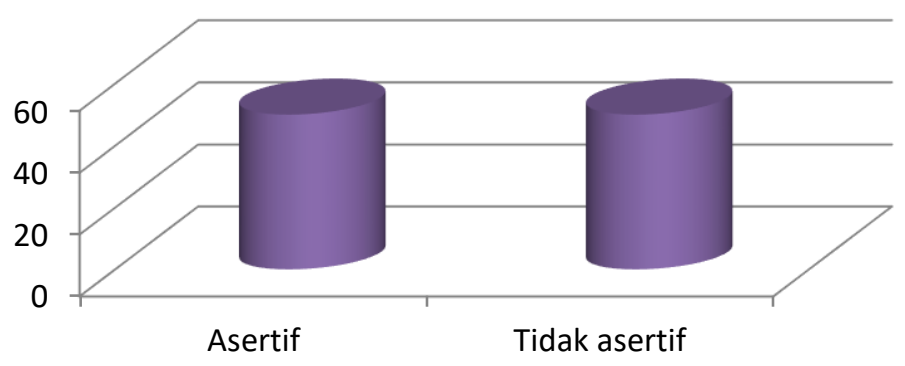

\section{Profil Perilaku Asertif Remaja Berdasarkan Indikator}

Setelah dipaparkan profil perilaku asertif remaja secara umum, pada paparan berikutnya disampaikan profil perilaku asertif remaja berdasarkan indikator. Secara lebih rinci diuraikan pada Tabel 3 berikut.

Tabel 3. Profil Perilaku Asertif Remaja LKSA Nugraha Tahun 2015 Berdasarkan Indikator

\begin{tabular}{|c|c|c|c|c|c|}
\hline No & Indikator & Kategori & $\begin{array}{l}\text { Rentang } \\
\text { Skor }\end{array}$ & Frekuensi & Presentase \\
\hline \multirow[t]{2}{*}{1.} & \multirow{2}{*}{$\begin{array}{l}\text { Hormat } \\
\text { Diri dan Orang Lain }\end{array}$} & Asertif & $\mathrm{X} \geq 11$ & 28 & 53,85 \\
\hline & & $\begin{array}{l}\text { Tidak } \\
\text { Asertif }\end{array}$ & $X<11$ & 24 & 46,15 \\
\hline \multirow[t]{2}{*}{2.} & \multirow[t]{2}{*}{ Berpikir Positif } & Asertif & $X \geq 8$ & 33 & 63,46 \\
\hline & & $\begin{array}{l}\text { Tidak } \\
\text { Asertif }\end{array}$ & $\mathrm{X}<8$ & 19 & 36,54 \\
\hline \multirow[t]{2}{*}{3.} & \multirow{2}{*}{$\begin{array}{l}\text { Bertanggung Jawab } \\
\text { Terhadap Pendapat } \\
\text { Yang Dituangkan }\end{array}$} & Asertif & $\mathrm{X} \geq 11$ & 22 & 42,31 \\
\hline & & $\begin{array}{l}\text { Tidak } \\
\text { Asertif }\end{array}$ & $X<11$ & 30 & 57,69 \\
\hline \multirow[t]{2}{*}{4.} & \multirow[t]{2}{*}{$\begin{array}{ll}\text { Terbuka } & \text { Terhadap } \\
\text { Perubahan } & \end{array}$} & Asertif & $\mathrm{X} \geq 10$ & 28 & 53,85 \\
\hline & & $\begin{array}{l}\text { Tidak } \\
\text { Asertif }\end{array}$ & $X<10$ & 24 & 46,15 \\
\hline 5. & Percaya Diri & Asertif & $X \geq 6$ & 33 & 63,46 \\
\hline
\end{tabular}




\begin{tabular}{|c|c|c|c|c|c|}
\hline & & $\begin{array}{l}\text { Tidak } \\
\text { Asertif }\end{array}$ & $X<6$ & 19 & 36,54 \\
\hline 6 & Penghargaan Diri & Asertif & $X \geq 24$ & 27 & 51,92 \\
\hline & & $\begin{array}{l}\text { Tidak } \\
\text { Asertif }\end{array}$ & $X<24$ & 25 & 48.07 \\
\hline 7 & Penerimaan Diri & Asertif & $\mathrm{X} \geq 7$ & 12 & 23,08 \\
\hline & & $\begin{array}{l}\text { Tidak } \\
\text { Asertif }\end{array}$ & $X<7$ & 40 & 76,92 \\
\hline 8 & Empati & Asertif & $\mathrm{X} \geq 6$ & 35 & 67,31 \\
\hline & & $\begin{array}{l}\text { Tidak } \\
\text { Asertif }\end{array}$ & $X<6$ & 17 & 32,69 \\
\hline 9 & Mendengarkan & Asertif & $\mathrm{X} \geq 4$ & 48 & 92,31 \\
\hline & & $\begin{array}{l}\text { Tidak } \\
\text { Asertif }\end{array}$ & $X<4$ & 4 & 7,69 \\
\hline 10 & $\begin{array}{l}\text { Melakukan Kontak } \\
\text { Mata Langsung }\end{array}$ & Asertif & $X \geq 15$ & 18 & 34,62 \\
\hline & & $\begin{array}{l}\text { Tidak } \\
\text { Asertif }\end{array}$ & $X<15$ & 34 & 65,38 \\
\hline 11 & $\begin{array}{l}\text { Postur Tubuh } \\
\text { Terbuka }\end{array}$ & Asertif & $X \geq 5$ & 23 & 44,23 \\
\hline & & $\begin{array}{l}\text { Tidak } \\
\text { Asertif }\end{array}$ & $X<5$ & 29 & 55,77 \\
\hline 12 & $\begin{array}{lr}\text { Menerima } & \text { dan } \\
\text { Memberi } & \text { Umpan }\end{array}$ & Asertif & $\mathrm{X} \geq 15$ & 25 & 48,07 \\
\hline & Balik & $\begin{array}{l}\text { Tidak } \\
\text { Asertif }\end{array}$ & $X<15$ & 27 & 51,93 \\
\hline 13 & $\begin{array}{l}\text { Berpartisipasi Dalam } \\
\text { Pergaulan }\end{array}$ & Asertif & $\mathrm{X} \geq 8$ & 27 & 51,93 \\
\hline & & $\begin{array}{l}\text { Tidak } \\
\text { Asertif }\end{array}$ & $X<8$ & 25 & 48,07 \\
\hline
\end{tabular}




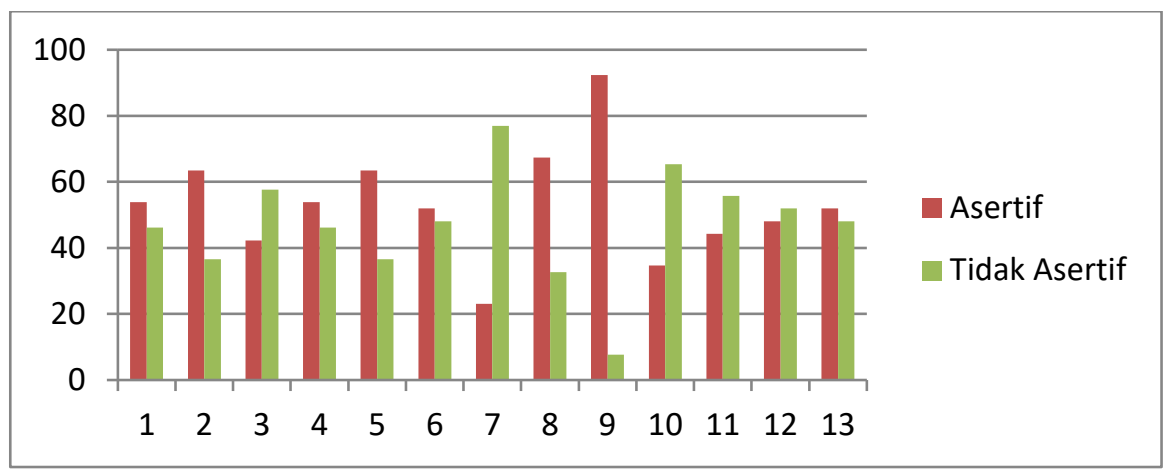

\section{A. Rumusan Hipotetik Role playing Untuk Mengembangkan Perilaku Asertif Remaja}

Rumusan hipotetik role playing untuk mengembangkan perilaku asertif remaja diuraikan kedalam dua sub pembahasan, yaitu: (a) uji kelayakan role playing menurut pakar dan praktisi; dan (b) deskripsi role playing untuk mengembangkan perilaku asertif per-sesi.

\section{Uji Kelayakan Role playing}

Role playing ini dikembangkan berdasarkan hasil kondisi awal profil perilaku asertif remaja LKSA. Adapun struktur role playing pada penelitian ini mengacu pada Fannie Shaffel dengan asumsi: (a) bermain peran dapat menggambarkan perasaan individu, baik perasaan yang hanya dipikirkan maupun yang diekspresikan; (b) emosi dan gagasan dapat digiring menuju sebuah kesadaran yang selanjutnya dikembangkan dalam kelompok; (c) proses psikologi secara tersembunyi yang melibatkan perilaku pribadi, nilai, dan sistem kepercayaan.

\section{Tabel 4. Matrik Teknik Role Playing Untuk Mengembangkan Perilaku Asertif Remaja}

\begin{tabular}{|c|c|c|c|c|c|}
\hline $\begin{array}{l}\text { Tahapan } \\
\text { Layanan }\end{array}$ & $\begin{array}{c}\text { Sesi } \\
\text { Layanan }\end{array}$ & Waktu & Tujuan & Deskripsi Kegiatan & $\begin{array}{c}\text { Penunjang } \\
\text { Teknis dan } \\
\text { Metode }\end{array}$ \\
\hline $\begin{array}{l}\text { Tahap } \\
\text { Awal } \\
\text { (Orientasi } \\
\text { ) }\end{array}$ & $\begin{array}{l}\text { Sesi 1 } \\
\text { Pengungk } \\
\text { apan } \\
\text { kondisi } \\
\text { awal } \\
\text { remaja } \\
\text { LKSA } \\
\text { (Pre-Test) }\end{array}$ & $\begin{array}{l}1 \mathrm{x} \\
\text { Pertemuan } \\
(1 \mathrm{x} 45 \\
\text { menit })\end{array}$ & $\begin{array}{l}\text { 1. Peserta dapat } \\
\text { memahami tujuan } \\
\text { umum dan garis } \\
\text { besar layanan. } \\
\text { 2. Peserta dapat } \\
\text { memahami tujuan } \\
\text { pengungkapan } \\
\text { perilaku asertif. }\end{array}$ & $\begin{array}{l}\text { Peneliti membagikan angket perilaku } \\
\text { asertif beserta lembar jawabannya. } \\
\text { Selanjutnya, menjelaskan cara } \\
\text { pengisian angket dan menugaskan } \\
\text { peserta untu mengisi lembar } \\
\text { jawaban. Dalam hal ini, peneliti } \\
\text { menegaskan pada peserta untuk } \\
\text { memilih jawaban yang } \\
\text { menggambarkan kondisi peserta. } \\
\text { Berikutnya, peserta mengisi lembar } \\
\text { jawaban dengan memilih salah satu } \\
\text { jawaban yang tersedia, kemudian } \\
\text { mengumpulkannya setelah selesai } \\
\text { mengerjakannya. Sebelum kegiatan }\end{array}$ & $\begin{array}{l}1 . \\
\text { Penunjang } \\
\text { Teknis: } \\
\text { Angket } \\
\text { perilaku } \\
\text { asertif. } \\
\text { 2. Metode: } \\
\text { Penugasa } \\
\text { n }\end{array}$ \\
\hline
\end{tabular}




\begin{tabular}{|c|c|c|c|c|c|}
\hline & & & & $\begin{array}{l}\text { berakhir, peneliti menyampaikan } \\
\text { bahwa hasil pengungkapan kondisi } \\
\text { awal profil perilaku asertif akan } \\
\text { diberikan pada pertemuan } \\
\text { berikutnya. }\end{array}$ & \\
\hline & $\begin{array}{l}\text { Sesi } 2 \\
\text { Pemaham } \\
\text { an umum } \\
\text { mengenai } \\
\text { perilaku } \\
\text { asertif } \\
\text { berdasark } \\
\text { an hasil } \\
\text { Pre-test }\end{array}$ & $\begin{array}{l}\mathrm{x} \\
\text { Pertemuan } \\
(1 \mathrm{x} 45 \\
\text { menit })\end{array}$ & $\begin{array}{l}\text { Peserta memahami } \\
\text { kondisi awal perilaku } \\
\text { asertif dirinya. }\end{array}$ & $\begin{array}{l}\text { Peneliti membagikan lembaran hasil } \\
\text { pengungkapan kondisi awal perilaku } \\
\text { asertif pada masing-masing peserta, } \\
\text { kemudian menjelaskannya. } \\
\text { Berikutnya, peserta menyimak } \\
\text { penjelasan tersebut dengan melihat } \\
\text { lembaran hasil pengungkapan kondisi } \\
\text { awal yang yang telah dibagikan } \\
\text { serta diarahkan untuk berperan aktif } \\
\text { dalam diskusi. Selanjutnya, peneliti } \\
\text { menjelaskan pentingnya layanan role } \\
\text { playing untuk mengembangkan } \\
\text { perilaku asertif remaja. Setelah itu, } \\
\text { peneliti mempersilahkan peserta } \\
\text { untuk bertanya mengenai perilaku } \\
\text { asertif. Sebelum kegiatan berakhir, } \\
\text { peneliti menyampaikan rangkaian } \\
\text { kegiatan selanjutnya dalam rangka } \\
\text { mengembangkan perilaku asertif. }\end{array}$ & $\begin{array}{l}\text { 1. Penunjan } \\
\text { g Teknis: } \\
\text { Hasil } \\
\text { pengungkap } \\
\text { an } \\
\text { kondisi } \\
\text { awal } \\
\text { perilaku } \\
\text { asertif. } \\
\text { 2. Metode: } \\
\text { diskusi } \\
\text { dan } \\
\text { tanya jawab }\end{array}$ \\
\hline $\begin{array}{l}\text { Tahap Inti } \\
\text { (Intervens } \\
\text { i terdiri } \\
\text { dari } 9 \text { sub } \\
\text { tahap } \\
\text { yang } \\
\text { dikelompo } \\
\text { kkan } \\
\text { kedalam } 5 \\
\text { sesi ) }\end{array}$ & $\begin{array}{l}\text { Sesi } 1 \\
\text { Pemanasa } \\
\mathrm{n} \text { dan } \\
\text { pemilihan } \\
\text { peran }\end{array}$ & $\begin{array}{l}1 \mathrm{x} \\
\text { Pertemuan } \\
(1 \mathrm{x} \quad 60 \\
\text { menit) }\end{array}$ & $\begin{array}{lr}\text { Peserta } & \text { dapat } \\
\text { mengembangkan } \\
\text { perilaku asertif } \\
\text { yang meliputi } \\
\text { indikator } \\
\text { penghormatan } \\
\text { terhadap diri dan } \\
\text { orang lain, } \\
\text { berpikir positif, } \\
\text { tanggung jawab } \\
\text { terhadap } \\
\text { pemikirannya dan } \\
\text { terbuka terhadap } \\
\text { perubahan. }\end{array}$ & $\begin{array}{l}\text { Peneliti mengemukakan tema } \\
\text { masalah yang diangkat dari } \\
\text { kehidupan sehari-hari peserta, yaitu } \\
\text { yang berkaitan dengan interaksi } \\
\text { sosial mereka terhadap teman } \\
\text { sebayanya, sehingga peserta } \\
\text { mengangap bahwa permasalahan } \\
\text { tersebut merupakan sebuah wadah } \\
\text { yang mewajibkan mereka untuk } \\
\text { belajar menghadapi sebuah masalah. } \\
\text { Selanjutnya, peneliti menggambarkan } \\
\text { permasalahan dengan jelas disertai } \\
\text { dengan contoh, yaitu melalui cerita. } \\
\text { Permasalahan tersebut muncul dari } \\
\text { gambaran yang diberikan oleh } \\
\text { peserta. Berikutnya, peserta } \\
\text { menyimak cerita yang dibacakan } \\
\text { oleh peneliti. Dalam hal ini, cerita } \\
\text { dihentikan saat sebuah dilema } \\
\text { muncul. Selanjutnya, peneliti } \\
\text { mengajukan pernyataan yang } \\
\text { membuat peserta berpikir dan } \\
\text { memperkirakan akhir cerita. } \\
\text { Setelah itu, peneliti dan peserta } \\
\text { berdiskusi untuk menggambarkan } \\
\text { berbagai karakter yang akan } \\
\text { diperankan. Penggambaran karakter } \\
\text { terbut diadasarkan atas tuntunan } \\
\text { cerita menurut persepsi peneliti dan } \\
\text { peserta. Berikutnya, peneliti } \\
\text { memberikan kesempatan kepada } \\
\text { peserta untuk mengemukakan }\end{array}$ & $\begin{array}{l}\text { 1. Penunjan } \\
\text { g Teknis: } \\
\text { SKLBK, } \\
\text { papan } \\
\text { tulis, } \\
\text { spidol } \\
\text { dan } \\
\text { jurnal } \\
\text { harian } \\
\text { kegiatan } \\
\text { 2. Metode: } \\
\text { Diskusi }\end{array}$ \\
\hline
\end{tabular}




\begin{tabular}{|c|c|c|c|c|}
\hline & & & $\begin{array}{l}\text { karakter yang dikehendaki, sesuai } \\
\text { dengan yang dirasakan peserta. } \\
\text { Selanjutnya, peneliti mengajukan } \\
\text { tawaran, siapa yang akan menjadi } \\
\text { pemeran. }\end{array}$ & \\
\hline $\begin{array}{l}\text { Sesi } 2 \\
\text { Pengatura } \\
\mathrm{n} \text { adegan } \\
\text { dan } \\
\text { penugasan }\end{array}$ & $\begin{array}{l}1 \mathrm{x} \\
\text { pertemuan } \\
(1 \times 60 \\
\text { menit })\end{array}$ & $\begin{array}{l}\text { Peserta dapat } \\
\text { mengembangkan } \\
\text { perilaku asertif } \\
\text { yang meliputi } \\
\text { indikator } \\
\text { Penerimaan diri dan } \\
\text { berpartisipasi dalam } \\
\text { pergaulan }\end{array}$ & $\begin{array}{l}\text { Peserta yang berperan menjadi } \\
\text { pemeran menyusun garis besar } \\
\text { adegan yang dimainkan. Dalam hal } \\
\text { ini, peneliti menegaskan pada } \\
\text { peserta bahwa mereka tidak perlu } \\
\text { mempersiapkan dialog khusus. } \\
\text { Peserta diminta hanya membuat } \\
\text { sketsa adegan dan perkiraan- } \\
\text { perkiraan tindakan seorang pemain. } \\
\text { Selanjutnya, peneliti berdiskusi } \\
\text { dengan peserta mengenai kebutuhan } \\
\text { yang diperlukan saat adegan. } \\
\text { Berikutnya, peneliti menugaskan } \\
\text { pada peserta yang berperan menjadi } \\
\text { pengamat untuk menilai: (1) peran } \\
\text { yang dimainkan oleh pemain apakah } \\
\text { sudah sesuai dengan keadaan yang } \\
\text { sebenarnya; (2) bagaimana } \\
\text { keefektifan pelaku yang ditunjukkan } \\
\text { pemeran; (3) apakah pemeran dapat } \\
\text { menghayati peran yang dimainkan. } \\
\text { Setelah itu, peneliti memberikan } \\
\text { kesempatan pada peserta untuk } \\
\text { bertanya perihal pengaturan adegan } \\
\text { dan penugasan. }\end{array}$ & $\begin{array}{ll}\text { 1. } & \text { Penunja } \\
\text { ng } \\
\text { teknis: } \\
\text { SKLBK } \\
\text {, papan } \\
\text { tulis, } \\
\text { spidol } \\
\text { dan } \\
\text { jurnal } \\
\text { harian } \\
\text { kegiatan } \\
\text { 2. Metode: } \\
\text { Diskusi, } \\
\text { dan } \\
\text { penugas } \\
\text { an. }\end{array}$ \\
\hline $\begin{array}{l}\text { Sesi } 3 \\
\text { Pemerana } \\
\text { n }\end{array}$ & $\begin{array}{l}1 \mathrm{x} \\
\text { Pertemuan } \\
(1 \mathrm{x} \quad 60 \\
\text { menit) }\end{array}$ & $\begin{array}{lr}\text { Peserta } & \text { dapat } \\
\text { mengembangkan } \\
\text { perilaku } & \text { asertif } \\
\text { yang } & \text { meliputi } \\
\text { indikator } & \text { percaya } \\
\text { diri, penghargaan } \\
\text { diri, } & \text { empati, } \\
\text { kontak } & \text { mata } \\
\text { langsung, } & \text { dan } \\
\text { postur } & \text { tubuh } \\
\text { terbuka } & \end{array}$ & $\begin{array}{l}\text { Pemain memainkan peran dan } \\
\text { menghidupkan situasi secara } \\
\text { spontan, dan saling merespon secara } \\
\text { realistis. Dalam hal ini, pemeranan } \\
\text { cukup dilakukan secara singkat, } \\
\text { sesuai dengan tingkat kesulitan dan } \\
\text { kompleksitas masalah serta jumlah } \\
\text { pemeran yang dilibatkan. } \\
\text { Selanjutnya peneliti dan peserta } \\
\text { melakukan diskusi dan evaluasi } \\
\text { mengenai penafsiran terhadap } \\
\text { pemeranan. Berikutnya, peneliti } \\
\text { memberikan kesempatan kepada } \\
\text { peserta untuk bertanya mengenai } \\
\text { pemeranan. }\end{array}$ & $\begin{array}{ll}\text { 1. } & \text { Penunja } \\
\text { ng } \\
\text { teknis: } \\
\text { SKLBK } \\
\text {, papan } \\
\text { tulis, } \\
\text { spidol. } \\
\text { 2. Metode: } \\
\text { bermain } \\
\text { peran, } \\
\text { dan } \\
\text { tanya } \\
\text { jawab. }\end{array}$ \\
\hline $\begin{array}{l}\text { Sesi } 4 \\
\text { Pemerana } \\
\text { ni Ulang }\end{array}$ & $\begin{array}{l}1 \mathrm{x} \\
\text { Pertemuan } \\
(1 \mathrm{x} 60 \\
\text { menit })\end{array}$ & $\begin{array}{lr}\text { Peserta } & \text { dapat } \\
\text { mengembangkan } \\
\text { perilaku } & \text { asertif } \\
\text { yang } & \text { meliputi } \\
\text { indikator } & \\
\text { menerima } & \text { dan } \\
\text { memberi } & \text { umpan } \\
\text { balik } & \end{array}$ & $\begin{array}{l}\text { Pemeranan ulang dilaukan jika } \\
\text { diskusi pada sesi pemeranan tidak } \\
\text { menghasilkan pemahaman utuh } \\
\text { kepada peserta mengenai kejadian } \\
\text { atau peran tertentu, peneliti meminta } \\
\text { reka ulang adegan. Peneliti memulai } \\
\text { kegiatan dengan mengajak peserta } \\
\text { berdiskusi mengenai penafsiran baru } \\
\text { tentang peran dan memutuskan siapa } \\
\text { yang akan kembali memainkan } \\
\text { peran. Dalam hal ini, pemeranan } \\
\text { ulang dilakukan berdasarkan diskusi }\end{array}$ & $\begin{array}{l}\text { 1. Penunja } \\
\text { ng } \\
\text { teknis: } \\
\text { SKLBK } \\
\text {, papan } \\
\text { tulis, } \\
\text { spidol. } \\
\text { 2. Metode: } \\
\text { bermain } \\
\text { peran, } \\
\text { dan } \\
\text { tanya }\end{array}$ \\
\hline
\end{tabular}




\begin{tabular}{|c|c|c|c|c|c|}
\hline & & & & $\begin{array}{l}\text { dan evaluasi alternatif pemeranan, } \\
\text { mungkin ada perubahan watak yang } \\
\text { dituntut. } \\
\text { Selanjutnya, peneliti menugaskan } \\
\text { kepada peserta yang yang berperan } \\
\text { menjadi pemain untuk melakukan } \\
\text { pemeranan ulang. Setelah itu peneliti } \\
\text { memberikan kesempatan kepada } \\
\text { peserta untuk bertanya perihal } \\
\text { pemeranan yang telah dilakukan. }\end{array}$ & jawab. \\
\hline & $\begin{array}{l}\text { Sesi } 5 \\
\text { Berbagi } \\
\text { Pengalam } \\
\text { an dan } \\
\text { Pengambil } \\
\text { an } \\
\text { Kesimpul } \\
\text { an }\end{array}$ & $\begin{array}{l}1 \mathrm{x} \\
\text { Pertemuan } \\
(1 \times 60 \\
\text { menit) }\end{array}$ & $\begin{array}{l}\text { Peserta dapat } \\
\text { mengembangkan } \\
\text { perilaku asertif } \\
\text { yang meliputi } \\
\text { indikator } \\
\text { mendengarkan } \\
\text { orang lain }\end{array}$ & $\begin{array}{l}\text { Peneliti mengajak peserta untuk } \\
\text { berdiskusi mengenai berbagai } \\
\text { pengalaman tentang permainan } \\
\text { peran yang dilakukan. Hal tersebut } \\
\text { dilakukan agar peserta dapat } \\
\text { bercermin pada orang lain untuk } \\
\text { lebih memahami dirinya. Selanjutnya } \\
\text { peneliti memberikan kesempatan } \\
\text { pada peserta untuk bertanya. } \\
\text { Berikutnya peneliti bersama peserta } \\
\text { mengambil kesimpulan dari kegiatan } \\
\text { bermain peran. }\end{array}$ & $\begin{array}{l}\text { 1. Penunja } \\
\text { ng } \\
\text { teknis: } \\
\text { SKLBK } \\
\text {, papan } \\
\text { tulis, } \\
\text { spidol } \\
\text { dan } \\
\text { jurnal } \\
\text { harian } \\
\text { kegiatan } \\
\text { 2. Metode: } \\
\text { Diskusi. }\end{array}$ \\
\hline $\begin{array}{l}\text { Tahapan } \\
\text { Akhir } \\
\text { (Refleksi) }\end{array}$ & $\begin{array}{l}\text { Refleksi } \\
(\text { Post- } \\
\text { test })\end{array}$ & $\begin{array}{l}\mathrm{x} \\
\text { Pertemuan } \\
(1 \mathrm{x} 45 \\
\text { menit })\end{array}$ & & $\begin{array}{l}\text { Peneliti membagikan angket perilaku } \\
\text { asertif beserta lembar jawabannya. } \\
\text { Selanjutnya, menjelaskan cara } \\
\text { pengisian angket dan menugaskan } \\
\text { peserta untuk mengisi lembar } \\
\text { jawaban. Dalam hal ini, peneliti } \\
\text { menegaskan pada peserta untuk } \\
\text { memilih jawaban yang } \\
\text { menggambarkan kondisi peserta. } \\
\text { Berikutnya, peserta mengisi lembar } \\
\text { jawaban dengan memilih salah satu } \\
\text { jawaban yang tersedia, kemudian } \\
\text { mengumpulkannya setelah selesai } \\
\text { mengerjakannya. }\end{array}$ & $\begin{array}{ll}\text { 1. } & \text { Penunja } \\
\text { ng } \\
\text { teknis: } \\
\text { angket } \\
\text { perilaku } \\
\text { asertif } \\
\text { 2. Metode: } \\
\text { Penugas } \\
\text { an }\end{array}$ \\
\hline
\end{tabular}

Role playing yang dimaksud dalam penelitian merupakan layanan yang diberikan kepada remaja agar dapat mengembangkan pemahaman dan keterampilan sosial sehingga dapat: (1) mencegah adanya konflik sosial yang deskonstruktif; (2) mengembangkan keterampilan komunikasi dalam berinteraksi sosial serta pemecahan masalah-masalah sosial; (3) membangun hubungan yang produktif; (4) meningkatkan penghormatan terhadap diri dan orang lain; (5) meningkatkan kapasitas untuk kerja sama secara produktif. Layanan tersebut dirancang berdasarkan aspek pikiran, perasaan, dan tindakan untuk mengembangakan perilaku asertif remaja.

Dalam rangka menghasilkan role playing yang teruji secara efektif, maka langkah awal yang dilakukan adalah dengan menguji kelayakan program secara rasional. Uji kelayakan program ini dilakukan melalui penilaian pakar dan praktisi (expert judgment). 


\section{Deskripsi Role playing}

Mekanisme penyelenggaraan role playing diberikan kepada remaja LKSA Nugraha yang berada pada kategori tidak asertif. Tahapan role playing untuk mengembangkan perilaku asertif remaja dilaksanakan berdasarkan kesepakatan antara peneliti, pihak LKSA, dan peserta, baik mengenai waktu ataupun tempat. Kegiatan dilaksanakan dalam 8 kali pertemuan, dalam kurun waktu 1 bulan dan diadakan dua kali dalam seminggu. Untuk pelaksanaan pre-test maupun posttest perilaku asertif diberikan waktu 45 menit, sedangkan untuk kegiatan role playing diberikan waktu selama 60 menit yang dibagi dalam beberapa sesi (pembagian waktu tiap sesi pertemuan yakni: 5 menit untuk langkah awal, 45 menit untuk kegiatan inti dan 10 menit untuk penutup).

\section{Gambaran Efektivitas Role playing untuk Mengembangkan Perilaku Asertif Remaja}

Pengujian efektivitas role playing untuk mengembangkan perilaku asertif remaja LKSA Nugraha Tahun 2015 dilakukan dengan analisis statistik non parametik yaitu: (a) uji Man Whitney terhadap gain score untuk membandingkan kelompok eksperimen dan kontrol, dan (b) uji Wilcoxon Signed Rank pada kelompok eksperimen untuk membandingkan skor sebelum dan sesudah diberikan role playing.

Hipotesis penelitian ini yaitu: "Role playing efektif untuk mengembangkan perilaku asertif remaja dibandingkan dengan bimbingan lain (kontrol) ". Adapun hipotesis statistiknya adalah sebagai berikut:

$\mathrm{H}_{\mathrm{o}}: \mu$ eksperimen $=\mu$ kontrol

$\mathrm{H}_{1}: \mu$ eksperimen $>\mu$ kontrol

\section{Uji Man Whitney Terhadap Gain Score}

Data pengisian angket perilaku asertif yang telah diperoleh dari kelompok eksperimen dan kontrol dianalisis menggunakan analisis statistik non parametrik uji Mann Whitney terhadap gain score antara kelompok eksperimen dan kelompok kontrol. Data penelitian skor total kelompok eksperimen dan kelompok kontrol dapat dilihat pada Tabel 5 di bawah ini.

\section{Tabel 5. Data Penelitian Skor Total Kelompok Eksperimen}

\begin{tabular}{|c|c|c|c|}
\hline \multirow{2}{*}{$\begin{array}{c}\text { Subjek } \\
\text { Penelitian }\end{array}$} & \multicolumn{3}{|c|}{ Perilaku Asertif } \\
\cline { 2 - 4 } & Pretest & Posttest & Gain Score \\
\hline 1. & 100 & 103 & 3 \\
\hline 2. & 113 & 119 & 6 \\
\hline 3. & 90 & 98 & 8 \\
\hline 4. & 89 & 95 & 6 \\
\hline 5. & 121 & 124 & 3 \\
\hline 6. & 87 & 110 & 23 \\
\hline 7. & 96 & 106 & 10 \\
\hline 8. & 87 & 98 & 11 \\
\hline
\end{tabular}




\begin{tabular}{|c|c|c|c|}
\hline 9. & 93 & 99 & 6 \\
\hline 10. & 103 & 112 & 9 \\
\hline 11. & 78 & 117 & 39 \\
\hline 12. & 71 & 106 & 35 \\
\hline 13. & 75 & 127 & 52 \\
\hline 14. & 80 & 118 & 38 \\
\hline 15. & 74 & 96 & 22 \\
\hline \multicolumn{3}{|c|}{ Total Rata-Rata } & 271 \\
\hline \multicolumn{3}{|c|}{} \\
\hline
\end{tabular}

Tabel 6. Data Penelitian Skor Total Kelompok Kontrol

\begin{tabular}{|c|c|c|c|}
\hline \multirow{2}{*}{ Subjek Penelitian } & \multicolumn{3}{|c|}{ Perilaku Asertif } \\
\cline { 2 - 4 } & Pretest & Posttest & Gain Score \\
\hline 1. & 87 & 72 & -15 \\
\hline 2. & 87 & 113 & 26 \\
\hline 3. & 83 & 82 & -1 \\
\hline 4. & 96 & 99 & 3 \\
\hline 5. & 99 & 93 & -6 \\
\hline 6. & 104 & 97 & -7 \\
\hline 7. & 100 & 93 & -7 \\
\hline 8. & 113 & 111 & -2 \\
\hline 9. & 119 & 95 & -24 \\
\hline 10. & 94 & 87 & -7 \\
\hline 11. & 113 & 113 & 0 \\
\hline 12. & 85 & 85 & 0 \\
\hline 13. & 97 & 97 & 0 \\
\hline \multicolumn{4}{|c|}{ Total } \\
\hline \multicolumn{3}{|c|}{ Rata-Rata } & -40 \\
\hline
\end{tabular}

Berdasarkan hasil analisis data Uji Mann Whitney $U$ terhadap gain score, nilai sig adalah 0,01, maka Ho ditolak. Hal ini menunjukkan bahwa hipotesis nol $\left(\mathrm{H}_{0}\right)$ ditolak, yang berarti terdapat perbedaan yang signifikan perilaku asertif remaja yang diberi perlakuan dengan yang tidak diberikan perlakuan role playing pada remaja LKSA Nugraha Tahun 2015. Dengan demikian, dapat disimpulkan bahwa role playing efektif untuk mengembangkan perilaku asertif remaja.

\section{Uji Wilcoxon Signed Rank}

Untuk mengetahui efektifitas role playing untuk mengembangkan perilaku asertif remaja pada kelompok eksperimen dilakukan uji Wilcoxon satu sisi. Statistik uji yang digunakan untuk pengujian hipotesis $\mathrm{H}_{0}: \mu_{\text {posttest }-\mu \text { pretest }}=0, \mathrm{H}_{1}$ $: \mu_{\text {posttest }-\mu \text { pretest }}>0$ adalah statistik uji $w_{+}$yang menyatakan banyaknya rang yang 
berasal dari selisih positif. Pada uji statistik satu sisi kanan, hipotesis nol ditolak jika jika $w_{+}>w_{\text {tabel }}$. Hasil perhitungan uji Wilcoxon pada Tabel 4.10 menunjukkan $w_{+}$sebesar 120 dan $w_{\text {tabel }}$ sebesar 30 . Taraf keyakinan $(\alpha)$ yang digunakan sebagai kriteria dasar pengambilan keputusan hipotesisnya adalah pada taraf signifikansi $5 \%$ atau $\alpha=0,05$. Dengan menggunakan kriteria tolak hipotesis nol jika $w_{+}>w_{\text {tabel }} 120>30$, maka hipotesis nol $\mathrm{H}_{0}$ ditolak. Hal tersebut menunjukkan role playing efektif untuk mengembangkan perilaku asertif remaja LKSA Nugraha Tahun 2015.

Adapun uji efektivitas role playing berdasarkan setiap indikator perilaku asertif menunjukkan bahwa pada indikator hormat terhadap diri dan orang lain mempunyai $w_{+}>w_{\text {tabel }}$ yakni 38>30 yang berarti indikator tersebut efektif meningkat setelah diberikan perlakuan. Indikator berpikir positif mempunyai $w_{+}$ $>w_{\text {tabel }}$ yakni 45>30 yang berarti indikator tersebut tersebut efektif meningkat setelah diberikan perlakuan. Indikator bertanggung jawab terhadap pendapat yang dituangkan mempunyai $w_{+}>w_{\text {tabel }}$ yakni $43>30$ yang berarti indikator tersebut efektif meningkat setelah diberikan perlakuan. Indikator terbuka terhadap perubahan mempunyai $w_{+}>w_{\text {tabel }}$ yakni 55>30 yang berarti indikator tersebut efektif meningkat setelah diberikan perlakuan. Indikator percaya diri mempunyai $w_{+}>w_{\text {tabel }}$ yakni 38,5>30 yang berarti indikator tersebut efektif meningkat setelah diberikan perlakuan. Indikator penerimaan diri mempunyai $w_{+}>w_{\text {tabel }}$ yakni 58,5>30 yang berarti indikator tersebut efektif meningkat setelah diberikan perlakuan. Indikator penghargaan diri mempunyai $w_{+}>w_{\text {tabel }}$ yakni 43>30 yang berarti indikator tersebut efektif meningkat setelah diberikan perlakuan. Indikator empati mempunyai $w_{+}<w_{\text {tabel }}$ yakni $9<30$ yang berarti perlakuan tidak efektif pada indikator tersebut.

Pada indikator mendengarkan orang lain mempunyai $w_{+}>w_{\text {tabel }}$ yakni64,5 $>30$ yang berarti indikator tersebut efektif meningkat setelah diberikan perlakuan. Indikator melakukan kontak mata langsung mempunyai $w_{+}>w_{\text {tabel }}$ yakni 40,5 > 30 yang berarti indikator tersebut efektif meningkat setelah diberikan perlakuan. Indikator postur tubuh terbuka mempunyai $w_{+}<w_{\text {tabel }}$ yakni $21,5<30$ yang berarti perlakuan tidak efektif pada indikator tersebut. Indikator menerima dan memberi umpan balik $w_{+}>w_{\text {tabel }}$ yakni $46>30$ yang berarti indikator tersebut efektif meningkat setelah diberikan perlakuan. Indikator berpartisipasi dalam pergaulan $w_{+}<w_{\text {tabel }}$ yakni $21<30$ yang berarti perlakuan tidak efektif pada indikator tersebut.

\section{PEMBAHASAN}

Pada bagian ini dideskripsikan pembahasan hasil penelitian yang meliputi: (1) profil perilaku asertif remaja; (2) gambaran keefektifan role playing untuk mengembangkan perilaku asertif remaja.

\section{A. Profil Perilaku Asertif Remaja}

Hasil penelitian menunjukkan profil perilaku asertif remaja di lima LKSA Kota Bandung secara umum yakni 50\% berada pada kategori asertif dan 50\% 
berada pada kategori tidak asertif. Hal tersebut dapat dipahami mengingat aspek kepribadian remaja yang menonjol dalam berinteraksi sosial adalah social cognition dan konformitas. Yusuf (2009) menyatan social cognition merupakan kemampuan memahami orang lain. Kemampuan ini mendorong remaja untuk menjalin hubungan sosial dengan teman sebaya, sedangkan konformitas adalah kecenderungan untuk meniru, mengikuti opini, pendapat, nilai, kebiasaan, kegemaran atau keinginan orang lain. Perkembangan konformitas dapat memberikan dampak positif maupun negatif, tergantung kepada siapa atau kelompok mana remaja tersebut melakukan konformitasnya.

Sementara itu, Sherif (Efendi, 2013) menyatakan bahwa remaja yang memiliki konformitas yang tinggi, ia akan mengikuti apa saja yang dikehendaki oleh kelompok teman sebayanya. Semakin rendah kepercayaan diri remaja terhadap penilaiannya sendiri, maka semakin tinggi konformitasnya.

Anindyajati dan Karima (2004) menyatakan remaja yang berperilaku asertif memiliki keyakinan serta keberanian untuk bertindak maupun berpendapat, walaupun tindakan dan pemikirannya berbeda dengan lingkungannya. Beberapa ahli (Rees dan Graham, 1991; Bishop, 2007; Fajarwati, 2013) menyatakan kebebasan mengungkapkan pikiran dan pendapat merupakan bagian dari perilaku asertif, dimana individu mampu mengungkapkan pikiran dan pendapatnya dengan jelas, langsung dan tepat dengan tetap menghormati dirinya sendiri dan orang lain. ${ }^{11}$ Perilaku asertif tidak dilatar belakangi oleh maksud-maksud tertentu, seperti untuk memanipulasi, memanfaatkan, memperdaya ataupun mencari keuntungan dari pihak lain, seperti yang dinyatakan oleh Butler (Towned, 2007) bahwa perilaku asertif merupakan life postion yang sehat (I'm Ok You're Ok).

Namun demikian, berdasarkan hasil survei, pada umumnya remaja LKSA belum sampai pada pencapaian perilaku asertif yang optimal. Berdasarkan persentase tertinggi sampai terendah pada kategori asertif yaitu mendengarkan orang lain $92,31 \%$, empati $67,31 \%$, percaya diri $63,46 \%$, berpikir positif $63,46 \%$, hormat $53,85 \%$, terbuka terhadap perubahan $53,85 \%$, berpartispasi dalam pergaulan $51,93 \%$, penghargaan diri $51,93 \%$, menerima dan memberi umpan balik 48,07\%, postur tubuh terbuka 44,23\%. Bertanggung jawab terhadap pendapat yang dituangkan $42,31 \%$, melakukan kontak mata langsung $34,62 \%$, dan penerimaan diri $23,08 \%$. Dari data tersebut menunjukkan bahwa terdapat aspek yang belum dikuasai optimal oleh remaja. Persentase terendah pada kategori asertif juga berada pada aspek perasaan yaitu pada indikator penerimaan diri.

Hurlock (1974) menyatakan penerimaan diri sebagai tingkat kemampuan dan keinginan individu untuk hidup dengan segala karakteristik dirinya. Individu yang dapat menerima dirinya diartikan sebagai individu yang tidak bermasalah dengan dirinya sendiri sehingga memiliki kesempatan untuk beradaptasi dengan lingkungan. ${ }^{12}$ 
Pernyataan Hurlock menekankan akan pentingnya penerimaan diri, remaja yang memiliki penerimaan diri yang positif dapat menerima kebihan maupun kekurangan yang ada di dalam dirinya. Proses remaja untuk dapat menerima dirinya tidak dapat muncul begitu saja, melainkan terjadi melalui serangkaian proses. Pada kenyataannya, tidak semua individu dapat menerima dirinya dikarenakan masing-masing individu memiliki ideal self, seperti yang dikemukakan oleh Hurlock bahwa individu yang memiliki self ideal yang lebih tinggi dibandingkan real self yang dimilikinya akan mengalami kesulitan dalam melangsungkan kehidupannya.

Menurut hasil penelitian Hartini (Gandaputra, 2009: 53) remaja LKSA cenderung mempunyai kepribadian inferior, pasif, apatis, menarik diri, mudah putus asa, penuh dengan ketakutan dan kecemasan sehingga sulit menjalin hubungan dengan orang lain. Hal tersebut jika tidak ditangani dengan baik akan menghambat tahap-tahap perkembangan remaja LKSA.

Lebih lanjut Hurlock (1974) menjelaskan beberapa kondisi yang mendukung reamaja untuk dapat menerima dirinya sendiri, yaitu: (1) pemahaman diri, merupakan persepsi tentang dirinya tentang dirinya sendiri yang dibuat secara jujur, tidak berpura-pura dan bersifat realistis; (2) harapan yang realistis. Harapan realistis muncul jika individu menentukan sendiri harapannya yang disesuaikan dengan pemahaman mengenai kemampuan dirinya, bukan harapan yang ditentukan oleh orang lain. Selain indikator penerimaan diri, persentase terendah berada juga pada indikator postur tubuh terbuka. Rees dan Graham (1991) menyatakan perilaku asertif juga dapat muncul dalam bahasa tubuh. ${ }^{13}$ Berbahasa tubuh secara asertif dilakukan dengan menyadari apa yang dikatakan tubuh sehingga dapat menerima pesan dari orang lain. Sementara itu, Lange dan Jakubowski (Novianti dan Tjalla, 2008) menyatakan bertindak asertif yang terpenting bukanlah apa yang dikatakan tetapi bagaimana menyatakannya.

Berperilaku asertif bukan merupakan hal yang mudah dilakukan oleh remaja, akan tetapi ini bukanlah hal yang tidak mungkin terjadi, seperti yang dinyatakan oleh Willis dan Daisley (Mariani dan Andriani, 2005) bahwa asertif merupakan suatu bentuk perilaku dan bukan merupakan sifat kepribadian seseorang yang dibawa sejak lahir, sehingga dapat dipelajari meskipun pola kebiasaan seseorang mempengaruhi proses pembelajaran tersebut.

Willis dan Daisley menegaskan bahwa semua orang dapat berperilaku agresif, pasif, maupun asertif. Sementara itu, Rakos (Mariani dan Andriani, 2005) berpendapat bahwa untuk berperilaku asertif, perlu dipelajari dan dilatih dibandingkan perilaku agresif dan pasif. Hasil survei memperlihatkan perilaku asertif remaja belum dikembangkan secara optimal. Sejalan dengan pemahaman tentang pengembangan perilaku asertif, Alberti dan Emmons (Peneva dan Mavrodiev, 2013, hlm. 8) menyatakan bahwa perilaku asertif perlu dikembangkan dalam diri setiap remaja agar memiliki kontrol diri dan mempunyai kemampuan untuk berkata "tidak" ketika menolak ajakan negatif 
teman. Remaja harus berani menolak secara kritis hal-hal yang dapat merugikan dan membahayakannya.

Alberti dan Emmons sepakat bahwa perilaku asertif bukan satu- satunya cara dalam menyelesaikan permasalahan, tetapi dengan berperilaku asertif, masalah dapat diselesaikan dengan baik dan memadai. ${ }^{14} \mathrm{Hal}$ serupa dinyatakan oleh Feinstherheim dan Baer (1980) bahwa individu perlu mengembangkan perilaku asertif dalam kehidupannya agar dapat menerima keterbatasan yang ada di dalam dirinya dengan tetap berusaha untuk mencapai apa yang diinginkannya, sehingga baik berhasil maupun gagal ia akan tetap memiliki harga diri dan kepercayaan diri.

Pada kenyatannya tidak semua remaja mampu berperilaku asertif bahkan memilih berperilaku tidak asertif, seperti berpura-pura, memendam perasaannya, atau sebaliknya bersikap agresif. Pratanti (Dahlan, 2015) menyatakan bahwa kebanyakan orang enggan bersikap asertif karena dalam dirinya ada rasa takut mengecewakan orang lain, takut jika akhirnya dirinya tidak lagi disukai atau pun tidak diterima. Keinginan untuk mempertahankan kelangsungan hubungan sering dijadikan alasan oleh remaja untuk bersikap tidak asertif. Padahal, dengan membiarkan diri untuk bersikap tidak asertif (memendam perasaan dan perbedaan pendapat), justru akan mengancam hubungan yang ada karena salah satu pihak kemudian akan merasa dimanfaatkan oleh pihak lain. Terkait dengan perkembangan perilaku asertif, tidak terlepas dari faktor-faktor yang mempengaruhinya, seperti yang dinyatakan oleh Rathus (1980): (1) jenis kelamin. Peranan pendidikan laki- laki dan perempuan sejak kecil sudah dibedakan di masyarakat. Laki- laki didik bersikap tegas. Masyarakat mengajarkan bahwa asertif kurang sesuai untuk perempuan, sehingga tampak bahwa perempuan lebih bersikap pasif; (2) kepribadian. Individu yang berperan aktif dalam komunikasi adalah yang memiliki kemampuan untuk mengungkapkan pikirannya secara langsung dan terbuka dengan pendapat orang lain; (3) inteleligensi. Individu yang berperilaku asertif memiliki intelegensi yang baik, sehingga apa yang dipikirkan dan dirasakannya dapat tersampaikan dengan baik kepada individu lain; (4) kebudayaan. Pertama kali individu mengenal kebudayaan dari keluarga. Kebudayaan membentuk kepribadian individu dalam melangsungkan interaksi sosial; (5) usia.

Perilaku asertif berkembang sepanjang hidup manusia. Semakin bertambahnya usia maka pengalaman seseorang juga akan terus berkembang, sehingga dengan semakin kompleksnya pengalaman, seseorang akan dapat belajar mengenai hal yang positif bagi dirinya.

\section{Efektivitas Teknik Role Playing untuk Mengembangkan Perilaku Asertif Remaja}

Efektivitas teknik role playing ditinjau dari segi aspek beserta indikator yang efektif dan tidak efektif serta analisis terhadap faktor yang tidak efektif 
dalam proses pelaksanaan di lapangan. Ketiga aspek yang diberikan kepada remaja pada proses pelaksanaan role playing yaitu: (1) aspek pikiran yang meliputi indikator penghormatan terhadap diri dan orang lain, berpikir positif, tanggung jawab terhadap pemikirannya, dan terbuka terhadap perubahan; (2) aspek perasaan yang meliputi percaya diri, penghargaan diri, penerimaan diri, dan empati; (3) aspek tindakan yang meliputi mendengarkan orang lain, kontak mata, postur tubuh terbuka, umpan balik, dan berpartisipasi dalam pergaulan.

Fakta yang ditemukan selama pelaksanaan role playing pada indikator empati memang lebih rendah. Hal ini terindikasi dari sebagian remaja LKSA Nugaraha yang cenderung tidak memberikan kesempatan kepada temannya saat diskusi berlangsung, bahkan mencemooh temannya dan mengeluarkan pernyataan- pernyataan yang menyinggung perasaan temannya.

Upaya yang dapat dilakukan untuk menumbuhkan empati remaja LKSA yaitu menggiringnya menuju kesadaran akan kepedulian terhadap orang lain disekitarnya. Sharon (Rina, 2015) menyatakan bahwa kesadaran akan keberadaan orang lain merupakan faktor penting untuk mengembangkan empati pada remaja. Selain itu juga, faktor kematangan kognitif berpengaruh terhadap kemampuan empati. Untuk memahami kondisi orang lain diperlukan kematangan kognisi bukan hanya sekedar proses berpikir, sehingga dapat memahami penderitaan orang lain tanpa harus benar-benar mengalaminya

Berikutnya, indikator yang tidak signifikan adalah postur tubuh terbuka. Rees dan Graham (1991) menyatakan perilaku asertif juga dapat muncul dalam bahasa tubuh. Berbahasa tubuh secara asertif dilakukan dengan menyadari apa yang dikatakan tubuh sehingga dapat menerima pesan dari orang lain. Sementara itu, Lange dan Jakubowski (Novianti dan Tjalla, 2008) menyatakan bertindak asertif yang terpenting bukanlah apa yang dikatakan tetapi bagaimana menyatakannya.

Selanjutnya, indikator yang tidak signifikan adalah berpartsipasi dalam pergaulan. Perkembangan sosial pada masa remaja merupakan puncak dari perkembangan sosial dari fase-fase perkembangan. Hurlock (1974) menyatakan salah satu tugas perkembangan masa remaja yang sulit adalah berhubungan dengan penyelesaian masalah sosial.

Fakta yang ditemukan selama pelaksanaan role playing pada indikator berpartisipasi dalam pergaulan, yaitu terdapat remaja yang memisahkan diri saat berkelompok, namun teman-temannya tidak menghiraukannya. Hurlock (1974) menyatakan remaja dalam pergaulannya dengan teman sebaya diperlukan tiga proses sosialisasi, yaitu: (a) belajar berperilaku yang dapat diterima secara sosial; (b) belajar memainkan peran yang dapat diterima, dan (c) perkembangan sosial. 


\section{KESIMPULAN}

\section{A. Kesimpulan}

Kesimpulan hasil studi dan pengembangan role playing untuk mengembangkan perilaku asertif remaja dipaparkan sebagai berikut.

1. Kesimpulan Umum

Penelitian ini menghasilkan teknik yang efektif untuk mengembangkan perilaku asertif remaja, yang telah dikembangkan secara teoretik dan empiris. Adapun prosedur penelitian yang ditempuh yaitu studi pendahuluan, pengembangan role playing, uji kelayakan role playing, dan uji coba role playing. Hasil studi menunjukkan bahwa role playing efektif untuk mengembangkan perilaku asertif remaja.

2. Kesimpulan Khusus

a. Profil umum perilaku asertif remaja LKSA menunjukkan kategori tidak asertif pada indikator penerimaan diri, kontak mata langsung, dan postur tubuh terbuka. Hal tersebut dikarenakan remaja LKSA cenderung mempunyai kepribadian inferior, pasif, apatis, dan menarik diri.

b. Rumusan hipotetik role playing untuk mengembangkan perilaku asertif remaja memiliki struktur yang menurut pakar dan praktisi bimbingan dan konseling dinilai sangat memadai untuk diujicobakan. Adapun struktur dan tahapan layanan role playing untuk mengembangkan perilaku asertif yakni: rasional, asumsi, tujuan, sintaksis, sistem sosial, sistem pendukung, evaluasi, dan SKLBK.

c. Role playing terbukti efektif untuk mengembangkan hampir semua indikator perilaku asertif, kecuali pada indikator empati (aspek perasaan, melakukan kontak mata langsung (aspek tindakan), dan postur tubuh terbuka (aspek tindakan) tidak signifikan.

\section{B. Rekomendasi}

Rekomendasi berikut ditujukan untuk kepentingan program studi bimbingan dan konseling, lembaga kesejahteraan anak (LKSA), dan penelitian selanjutnya. Secara lebih rinci diuraikan sebagai berikut.

1. Program Studi Bimbingan dan Konseling

Teknik Role playing merupakan layanan yang diberikan kepada setiap individu agar dapat mengembangkan pemahaman dan keterampilan sosial. Program studi bimbingan dan konseling dapat memperkaya role playing untuk mengembangkan perilaku asertif dengan cara mengevaluasi dan merevisi kurikulum terkait dengan mata kuliah landasan bimbingan dan konseling. Hal tersebut ditujukan untuk meningkatkan kinerja calon guru BK. Selain itu juga, program studi bimbingan dan konseling dapat membuat kurikulum tentang peranan role playing di masyarakat, sehingga mahasiswa tidak hanya terpaku pada konteks pemberian layanan bimbingan di pendidikan formal saja. 


\section{Lembaga Kesejahteraan Sosial Anak (LKSA)}

Hasil penelitian menunjukkan bahwa indikator perilaku asertif berkaitan dengan keterampilan remaja dalam menyelesaikan pemasalahan sosial. Oleh karena itu rekomendasi penelitian ini antara lain:

a. Pihak LKSA dapat menggunakan instrumen perilaku asertif (terlampir) untuk mengungkap perilaku remaja sebagai dasar dalam mengembangkan metode.

b. Pihak LKSA dapat mengaplikasikan role playing dengan tahapan: (1) orientasi, yang meliputi pengungkapan kondisi awal dan pemahaman umum; (2) inti, yang meliputi pemanasan dan pemilihan peran, pengaturan adegan dan penugasan, pemeranan, pemeranan ulang; dan (3) akhir (refleksi).

3. Penelitian Selanjutnya

Rekomendasi pada penelitian selanjutnya didasarkan pada keterbatasan penelitian yang meliputi: (a) objek penelitian, (b) metode penelitian, dan (3) instrumen penelitian.

a. Pada penelitian ini, objek penelitian terbatas pada remaja usia 15-17 tahun di lima tempat LKSA, sehingga pada penelitian selanjutnya direkomendasikan memperluas objek penelitian pada remaja usia 13-17 tahun di berbagai tempat LKSA.

b. Metode yang digunakan dalam penelitian ini adalah eksperimen kuasi. Prosedur eksperimen kuasi hanya sampai pada ujian terbatas dimana produk penelitian yakni "Role playing" di uji cobakan pada kelompok eksperimen dengan tujuan untuk mengetahui keefektifan role playing dalam mengembangkan perilaku asertif. Sehingga pada penelitian selanjutnya direkomendasikan untuk menggunakan metode penelitian $\mathrm{R} \& \mathrm{D}$, dimana pengujian metode tidak hanya berakhir pada uji coba terbatas, melainkan juga dikembangkan pada tahap uji coba lebih luas, sehingga metode dapat digunakan pada sampel diluar kelompok uji terbatas.

c. Instrumen yang digunakan dalam penelitian ini adalah berupa angket berskala pengungkap perilaku asertif, sehingga respon dan pendapat pihak yang sering berinteraksi dengan sampel penelitian seperti pembina LKSA cenderung tidak terakomodasi. Penelitian selanjutnya diharapkan melakukan observasi, wawancara dengan pembina LKSA untuk mendapatkan data yang lebih akurat.

\section{DAFTAR PUSTAKA}

Alberti, R. \& Emmons, M. (2008). Your Perfect Right: Assertiveness and Equality in Your Life and Relationships (9th.ed). Atascadero, California: Impact Publisher.

Anindyajati, M. \& Karima, C. (2004). Peran Harga Diri Terhadap Assertivitas Remaja Penyalahgunaan Narkoba. Jurnal Psikologi. 2(1). 49-73. 
Bıçakç1, M. (2011). Analysis Of Social Adaption and friend relationships among adolescent living in orphanage and adolescent living with their family. Social and Natural Sciences Journal. 3. 25-30.

Bishop, S. (2006). Develop Your Assertiveness.London: Kogan Page.

Creswell, J. (2008), Educational Research, New Jersey: Pearson Education

Dahlan, H. T. (2011). Model Konseling Singkat Berfokus Solusi (Solution- Focused Brief Counseling) dalam Setting Kelompok untuk Meningkatkan Daya Psikologis Mahasiswa. Disertasi Doktor pada FIP UPI Bandung: tidak diterbitkan.

Effendi, M. (2013). Hubungan Antara Konsep Diri dan Pola Asuh Orang Tua Dengan Konformitas Santri. Jurnal Penelitian Humaniora. 14(1). 1-8.

Encheva, I. (2010). Assertiveness in The Personal Profile of Adolescents. Trakia Journal of Sciences. 8(3). 376-380

Fajarwati, A. (2012). Teknik Konseling Assertive Training Untuk Meningkatkan Tanggung Jawab Pribadi Siswa di SMP Negeri 1 Batu Jajar. Tesis pada jurusan BK UPI Bandung: Tidak diterbitkan.

Fensterhim \& Bear. (1980). Jangan Bilang YA Bila Anda akan Mengatakan Tidak. Jakarta: Gunung Jati.

Heppner, P., Wampold, E.B., \& Kivlinghan, M.D. (2008). Research Design in Counseling. USA: Thomson Higher Education.

Hurlock, E. (1974). Adolescent development. Tokyo: Mc Graw- Hill Kogakusha.

Joyce,B., Weil, M., dan Calhoun, E. (2011). Models of Teaching. Boston: Allyn \& Bacon.

Marini, L. \& Andriani, E. (2005). Perbedaan Asertivas Remaja Ditinjau Dari Pola Asuh Orang Tua. Jurnal Pemikiran \& Penelitian Psikologi. 2. 46-5.

Novianti, Christina, dan Tjalla. (2008). Assertive Behavior on Early Teen. Universitas Gunadarma. [online]. Tersedia: http://www.gunadarma.ac.id.

Peneva, I. \& Mavrodiev, S. (2013). A Historical Approach to Assertiveness. Journal of Psychological Thought. 6, (1). 3- 26.

Pipas, M. \& Jaradat, M. (2010). Assertive Communication Skills. Annales Universitatis Apulensi Series Oeconomica. 12, (2). 649-656.

Rathus, S., \& Nevid, J. (1980). Behavior Therapy of Solving Problem in Living. New York : The New AmericanLibrary, Inc.

Rees, S. \& Graham, R. Assertion Training. (.2006). Taylor: Routledge

Sugiyono. (2010). Metode Penelitian Pendidikan Pendekatan Kuantitatif , Kualitatif, dan $R \& D$.Bandung: Alfabeta.

Sukardi, K. \& Kusmawati, N. (2008). Proses Bimbingan dan Konseling di Sekolah. Jakarta: Rineka Cipta.

Tohirin. (2007). Bimbingan dan Konseling. Jakarta: Rineka Cipta.

Towned, A., Assertiveness and Diversity, (New York: Palgrave Macmillan, 2007), hal.13. 
Jayanti, T. (2012). Mengurangi Perilaku Siswa Tidak Tegas Melalui Teknik Assertive Training. 1, (1). 1-5.

Yusuf, S. ( 2009). Program Bimbingan dan Konseling di Sekolah. Bandung: Rizqi. 